\title{
Comparison of the Growth Potential of Macrobrachium rosenbergii in Mono and Polyculture Conditions in Earthen Culture Ponds of Jammu, India
}

\author{
Sanjeev Kumar Karlopia ${ }^{1}$, Yahya Bakhtiyar ${ }^{2 *}$ and Seema Langer ${ }^{1}$ \\ 'Department of Zoology, University of Jammu, Jammu - 180006, India; s.karlopia@gmail.com, langerseema@yahoo.co.in \\ 2Department of Zoology, University of Kashmir, Srinagar - 190006, India; yahya.bakhtiyar@uok.edu.in
}

\begin{abstract}
The study was conducted to assess the growth and survival of Macrobrachium rosenbergii in earthen culture ponds in order to know about the growth potential of $M$. rosenbergii in mono as well as polyculture conditions in Jammu. Polyculture experiments of prawn with some selected carps Indian Major Carps (Cirrhinus mrigala and Labeo rohita) and Exotic Carps (Cyprinus carpio) were undertaken in 3 freshwater ponds for duration of 4 months. Under the monoculture conditions, prawns attained an average size of $10.40 \pm 0.17 \mathrm{~cm}$ weighing $23.84 \pm 0.32 \mathrm{~g}$ in 4 months and the survival rate was found to be more than $75 \%$. The growth rate of prawns was found to increase steadily during the first half (upto mid-October) after which a decline in the growth rate was evident as the mean temperature reached below $18^{\circ} \mathrm{C}$. In the polyculture ponds the prawns attained an average size of $10.10 \pm 0.03 \mathrm{~cm}$ weighing $18.39 \pm 0.89 \mathrm{~g}$ (without $C$. carpio) and $8.4 \pm 0.36 \mathrm{~cm}$ weighing $15.23 \pm 0.36 \mathrm{~g}$ (with C. carpio) in 4 months and their survival rate was less than $70 \%$. Prawns being benthic feeders utilized the leftover food (of the fishes) that settled at the bottom, therefore, saving the feed cost. It was observed that mean size of the fish attained in the polyculture practice was almost similar to that obtained in the monoculture. The ideal prawn polyculture should be practiced with fast growing compatible carps such as Rohu and grass carp. Bottom feeder carps such as Mrigal (C. mrigala) should be avoided in prawn polyculture practice as they compete with prawns in feeding.
\end{abstract}

Keywords: Indian Major Carps and Growth, Monoculture, M. rosenbergii, Polyculture

Abbreviations used: ( $\mathbf{T}_{1}-$ Only $M$. rosenbergii), $\left(\mathbf{T}_{2}-\right.$ M.rosenbergii,C.mrigalaand L.rohita), and $\left(\mathbf{T}_{3}-\right.$ M.rosenbergii, C. mrigala, L. rohita and C. carpio). (MR-I) Monoculture and (MR-II) in Polyculture with two carps and (MR-III) with three carps. (MR) M. rosenbergii, (CM) C. mrigala, (LR) $L$. rohita and (CC) C. carpio.

\section{Introduction}

Macrobrachium rosenbergii (de Man, 1879) ${ }^{\underline{1}}$ is a freshwater prawn, commonly known as 'Scampi' or 'giant freshwater prawn' commonly distributed in fresh as well as in brackish water and estuaries 2 . The production of freshwater prawn M. rosenbergii gained popularity since 1995 and China is the topmost producer followed by India, Thailand and Bangladesh ${ }^{3}$. India being the second largest contributor of freshwater prawns to the world market has undergone a phenomenal growth in the past two decades. Freshwater prawns are important in the capture and culture fisheries and are extensively distributed in freshwater and estuaries of the world mostly in tropical and subtropical areas. Freshwater prawn culture is an aquaculture business designed to raise and produce freshwater prawn for human consumption ${ }^{4}$.

Out of 125 species of Macrobrachium, only a small number (M. rosenbergii, M. malcolmsonii, M. birmanicum, M. choprai etc.) have been exploited from the culture point of view. The giant freshwater prawn M. rosenbergii dominates the shell fish production currently because of its faster growth and adaptation to the environment and acceptance of artificial feed. The desire to culture $M$. rosenbergii has persisted since the first success at controlled production of juveniles of this prawn was achieved ${ }^{5}$. Minimizawa and Morizane (1970) ${ }^{\underline{6}}$ successfully cultured all larval stages using newly hatched nauplii of brine shrimp. Later, monoculture ${ }^{z}$ and polyculture with a

${ }^{*}$ Author for correspondence 
variety of fish species ${ }^{8}$ have been successfully undertaken. The culture of freshwater prawn is very popular in South East Asian countries and South American countries. Moreover, the polyculture of $M$. rosenbergii with Chinese and Indian major carps have been reported from different parts of the world in recent years ${ }^{9-11}$. Ranjeet and Kurup (2002) $)^{12}$. reported that $M$. rosenbergii is one of the most desirable candidate species for freshwater aquaculture in different parts of the Indo-Pacific region.

Several investigators $\frac{13,14}{}$ also witness successful rearing of fish and prawn larvae using live feed as exclusive diet. The breakthrough in its seed production and larval rearing technology has led to a new wave of enthusiasm among the prawn farmers for its monoculture and polyculture along with fish species like catla (Catlacatla), rohu (Labeo rohita) and mrigal (Cirrhinus cirrhosus). Paddy fields, homestead ponds and coconut garden channels are used for the culture of $M$. Rosenbergii ${ }^{15}$. M. rosenbergii is cultured either alone (monoculture) or in combination with carps (polyculture).

After studies on M. Dayanum ${ }^{16-20}$ and establishment of $M$. rosenbergii for the last 8 to 9 years in Jammu ${ }^{21,22}$ first attempt has been made to study the growth of $M$. rosenbergii under mono and polyculture conditions in earthen ponds of Jammu region, the Northern part of India.

\section{Materials and Methods}

\subsection{Rearing Units and Procedure}

Experiment was conducted in the field ponds at village Rakh, near Sarore, located at a distance of about 12 kilometres from Jammu City. The experiment was carried out for a period of 4 months (August to November, 2009).

\subsection{Experimental Ponds and Culturable Species}

Three ponds comprised an area of 0.2 hectare and 0.1 hectare i.e., one pond of 0.2 hectare and two ponds 0.1 hectare each were used for the study. Before stocking, the ponds were prepared by following all the conventional pre-stocking procedures. The ponds were completely drained and elimination of unwanted/predatory fishes was removed by hand picking. After drying, the ponds were maintained at 1.5 metre during the study period, compensating the loss of water due to seepage and evaporation of water. The fertilization was carried out with application of cow dung at the rate of 10 tons/hectare/ year; one fifth of which was applied two weeks prior to stocking of fish fries and prawn larvae as basal dose. The remaining amount was applied in equally divided doses at fortnightly intervals. Further inorganic fertilizers in the form of nitrogen and phosphates were applied fortnightly in split doses. Liming by $\mathrm{CaCO}_{3}$ (Calcium Carbonate) was done at intermittent interval of one month at the rate of $80 \mathrm{~kg} / \mathrm{hect}$ to maintain the desired $\mathrm{pH}$ of water and also for pond hygiene ${ }^{23}$.

\subsection{Stocking of Fish and Prawns}

Larvae of M. rosenbergii (whichwerebroughtfrom CIFEsub centre Rothak in oxygen packed containers) were stocked in three different ponds with different densities of carps (C. mrigala, L. rohita, C. carpio) keeping the density of prawns (M. rosenbergii) constant and each density was treated as treatment. The experimental carps were brought from two different farms of the Jammu and Kashmir department of fisheries viz. National Fish seed farm Kathua and Gho-Manhasa Fish farm Jammu. Layout of the experiment designed is shown in the (Table A).

Table A. Layout of the experimental design for the mono and polyculture of $M$. rosenbergii with the Carps

\begin{tabular}{|l|c|c|c|}
\hline \multirow{2}{*}{ Species } & \multicolumn{3}{|c|}{ Stocking density/0.1 hectare } \\
\cline { 2 - 4 } & $\mathbf{T}_{1}$ (MR-1) & $\mathbf{T}_{2}$ (MR-2) & $\mathbf{T}_{3}$ (MR-3) \\
\hline M. rosenbergii & 10000 & 10000 & 10000 \\
C. mrigala & $\mathrm{Nil}$ & 2000 & 2000 \\
L. rohita & $\mathrm{Nil}$ & 2000 & 2000 \\
C. carpio & $\mathrm{Nil}$ & $\mathrm{Nil}$ & 2000 \\
\hline
\end{tabular}

Mean initial weight of prawns, C. mrigala, L. rohita and C. carpio were recorded and pieces of pipes were placed in the pond for shelter.

\subsection{Feed and Feeding Rates}

Prawns and fishes were fed commercial fish feed jalpari and godrej. Composition of the feed given in the (Table B) twice a day at 10:00 and 15:00 hrs. The feeding quantity was adjusted at monthly intervals as per the biomass increase, as could be determined through intermittent sampling. 
Table B. Proximate composition of the formulated feed used for both mono and polyculture of $M$. rosenbergii with the Carps

\begin{tabular}{|c|c|c|}
\hline S. No. & Ingredients & Percentage (\%) \\
\hline 1. & Proteins & 27.5 \\
\hline 2. & Fats & 3.5 \\
\hline 3. & Moisture & 10.0 \\
\hline 4. & Calcium & 1.0 \\
\hline 5. & Phosphorous & 0.5 \\
\hline 6. & Lysine & 1.3 \\
\hline 7. & Energy & $2650 \mathrm{~K} \mathrm{Cal}$. \\
\hline
\end{tabular}

\subsection{Monitoring of Water Quality Parameters}

Various water quality parameters such as temperature, $\mathrm{DO}, \mathrm{pH}$ etc. were monitored at regular intervals during the experimental period.

\subsection{Growth Parameters and Survival}

Various growth parameters were estimated at weekly intervals in terms of Body Weight Gain (BWG), Percentage Weight Gain (\%WG), Average Individual Body Length (AIBL), Total Length Gain (TLG), Average Individual Body Weight (AIBW), Specific Growth Rate (SGR), Feed Conversion Ratio (FCR), Feed Conversion Efficiency (FCE) and Survival by using the following formulae:

\begin{tabular}{|c|c|c|}
\hline TLG $(\mathrm{cm})$ & $=$ & $\begin{array}{l}\text { Average Final Length - Average } \\
\text { Initial Length. }\end{array}$ \\
\hline BWG (g) & $=$ & $\begin{array}{l}\text { Average Final Weight - Average } \\
\text { Initial Weight. }\end{array}$ \\
\hline$\% W G(\%)$ & $=$ & $\begin{array}{l}\text { (Average Final Weight }- \text { Average } \\
\text { Initial Weight }) \times 100 / \text { Average } \\
\text { Initial Weight. }\end{array}$ \\
\hline SGR (\%) & $=$ & $\begin{array}{l}100 \times \ln (\text { Final live weight)-ln } \\
(\text { Initial live weight } / \text { Experimental } \\
\text { period. }\end{array}$ \\
\hline FCR & $=$ & $\begin{array}{l}\text { weight of feed consumed/weight } \\
\text { gain of fish. }\end{array}$ \\
\hline
\end{tabular}

Survival rate $(\%)=100 \times$ No. of organisms found at the end of experiment/Total No. of organisms stocked

\section{Statistical Analysis}

The data was analysed to test the level of significance with the help of Microsoft Excel and SPSS (12.0 version,
Chicago, USA). The level of significance was tested by one way analysis of variance (ANOVA), Post Multiple Comparisons ${ }^{24}$.

\section{Results and Discussions}

Growth performance of prawns in mono and polyculture systems with respect to weight gain (g), Specific Growth Rate (SGR) and survival were calculated as depicted in (Tables 1, 2 and 3). The $M$. rosenbergii larvae were stocked in three different treatments. As is evident from (Tables 1-3), the initial mean length of prawn larvae was $3.40 \pm 0.17 \mathrm{~cm}, 3.80 \pm 0.0 .45 \mathrm{~cm}$ and $3.80 \pm 0.10$ $\mathrm{cm}$ respectively for $1^{\text {st }}, 2^{\text {nd }}, 3^{\text {rd }}(M R-1, M R-2, M R-3)$ treatment. The final mean length at the end of the trial period showed differences among different treatments and it decreased with the treatment from $1^{\text {st }}$ (MR-1) to $3^{\text {rd }}$ (MR-3). The M. rosenbergii larvae under treatment $1^{\text {st }}$ (MR-1) Monoculture, showed the highest final mean length $(10.40 \pm 0.173 \mathrm{~cm})$ followed by the $2^{\text {nd }}$ treatment, MR-2 i.e., Polyculture with two carp species (10.10 \pm $0.30 \mathrm{~cm}$ ) and lowest in the third treatment, MR-3 i.e., polyculture with three carp species $(8.4 \pm 0.360 \mathrm{~cm})$. Further, it was observed that the final mean length under the treatment $1^{\text {st }}$ (MR-1) was significantly different $(\mathrm{p} \leq 0.05)$ from the MR-3 but did not show any significant difference ( $p \geq 0.05$ ) from MR-2. Moreover, MR-2 also differed significantly from the MR-3.

Similarly, the perusal of (Tables 1-3) reveals that the initial mean weight of prawn larvae was $0.57 \pm 0.01 \mathrm{~g}$, $0.59 \pm 0.02 \mathrm{~g}$ and $0.47 \pm 0.12 \mathrm{~g}$ respectively for $1^{\text {st }}, 2^{\text {nd }}$ and $3^{\text {rd }}$ (MR-1, MR-2, MR-3) treatment. The final mean weight at the end of the trial period also showed great differences among different treatments and it decreased with the treatment from $1^{\text {st }}$ (MR-1) to $3^{\text {rd }}$ (MR-3). The $M$. rosenbergii larvae under treatment $1^{\text {st }}(\mathrm{MR}-1)$ showed the highest final mean weight $(23.84 \pm 0.32 \mathrm{~g})$ followed by the $2^{\text {nd }}$ treatment, MR-2 $(18.39 \pm 0.89 \mathrm{~g})$ and lowest in the third treatment, MR-3 (15.23 $\pm 0.36 \mathrm{~g})$. It was observed that the final mean weight under the treatment $1^{\text {st }}$ (MR-1) was significantly different $(\mathrm{p} \leq 0.05)$ from the MR-2 and MR-3. Moreover, MR-2 also differed significantly from the MR-3. The results of percentage mean weight gain was also found to be highest in treatment $1^{\text {st }}(M R-1)$ and found to be significantly different from MR-2 and MR-3.

The results found were in agreement with the findings of Chowdhury et al., (1991) ${ }^{25}$ and Tidwell et al., (2004) who also opined that the lowest stocking density gave 
relatively high growth. A wide variation in size, as observed in the present study is an uncommon phenomenon in M. rosenbergii as Fujimura and Okamoto (1970) $)^{27}$ have reported an average weight of $13.5 \mathrm{~g}$ after ten months as well as in seven and half months period. Tunsutapanich et al., (1980) ${ }^{28}$ have reported the same to be $42.1 \mathrm{~g}$ while Popper and Davidson (1982) 29 have reported $26.0 \mathrm{~g}$ of average weight of $M$. rosenbergii after a cultivation period of eight months. Shirgur et al.(1988) $\frac{30}{}$ recorded a wide variation in mean growth from $13.28 \mathrm{~g}$ to $28.9 \mathrm{~g}$ within seven months of culture duration. Raje and Joshi (1992) $)^{31}$ achieved average weight from $33.0 \mathrm{~g}$ to $160 \mathrm{~g}$ in 9 to 10 months of culture period. Similar results were also found by Indulkar et al., (2007) $)^{32}$ where average final weight of M. rosenbergii ranged from $41.7 \mathrm{~g}$ to $78.2 \mathrm{~g}$ in monoculture and $36.5 \mathrm{~g}$ to $50.4 \mathrm{~g}$ in polyculture ponds over a period of 8 months.

Results also revealed that the Specific Growth Rate (SGR) of prawns was found to be $3.108 \pm 0.084$, $2.88 \pm 0.14$ and $2.85 \pm 0.11$ for the treatment $1^{\text {st }}\left(\right.$ MR-1), $2^{\text {nd }}(M R-2)$ and $3^{\text {rd }}$ (MR-3) wherein higher SGR of $M$. rosenbergii started to decrease from treatment $1^{\text {st }}$ to $3^{\text {rd }}$. Statistical analysis also reveals SGR of MR- 1 to be significantly different from rest of the two whereas SGR of MR-2 and MR-3 do not show any significant difference among each other. These results are in full agreement with the results of Tidwell et al., (2004) ${ }^{26}$. Similarly, El-Sherif and Ali-Mervat (2009) ${ }^{33}$ found in their results that the SGR decreased with increase in density. Haque et al., (2003) $)^{34}$ on the other hand found a significant increase from low density to high density and similar pattern was also witnessed by some authors $\mathrm{s}^{25,35}$.

Survival at the end of the culture period was found to be $75.5 \pm 5.0 \%, 62.10 \pm 5.0 \%$ and $52.70 \pm 5.0 \%$ in MR-1, MR-2 and MR-3 respectively. The survival rates of all the treatments were found to be significantly different $(\mathrm{p} \leq 0.05)$ from each other. In other words, survival rate of $M$. rosenbergii in monoculture was found to be more than polyculture. Under comparable conditions, Shirgur et al., (1988) $)^{30}$ got $60.5 \%$ to $68.3 \%$ survival rate after 7 months and Raje and Joshi (1992) 31 $^{-1}$ could get 33\% to 50\% survival after 9 to 10 months of culture period. Similarly, according to Haque et al., (2003) $)^{34}$, the highest survival rate (85\%) of $M$. rosenbergii was recorded in treatment $\mathrm{T}_{1}$ (15 prawn, 15 catla, 15 rohu and 15 mrigal) and lowest in case of T6 (40 prawn, 15 catla, 15 rohu, 15 mrigal), which might be due to the increase of stocking density. Hoq et al., (1996) reported the survival rate of prawn to range from $32.22 \%$ to $75.5 \%$, which supports the present finding as well. Our results were also comparable with the results found by Hossain and Kibria (2006) $)^{36}$ that got $70.0-76.3 \%$ of prawn survival and also with the values reported by many workers $\frac{37-39}{}$.

Table 2 revealed that $C$. mrigala shows significantly high growth than the L. rohita in polyculture set up. Further, (Table 3) shows maximum growth in case C. carpio, followed by C. mrigala and finally $L$. rohita. Statistically, values differed significantly from each other $(p<0.05)$. Bottom feeders (C. carpio and C. mrigala) performed better growth rate against that of $L$. rohita probably due to the fact that being surface and column dweller, L. rohita is more sensitive to oxygen depletion, while being bottom dwellers, C. carpio and C. mrigala are more tolerant to fluctuation of oxygen concentration ${ }^{40}$. Among bottom feeders, growth performance of $C$. carpio appeared to be much better than C. mrigala probably due to their superior feed utilizing capability ${ }^{41}$. Mohanty (2003) ${ }^{42}$ however, while carrying out experiments to evaluate feed intake pattern, growth and yield performance of fish and prawn found that irrespective of stocking density, faster growth rate could be recorded in $C$. catla followed by C. carpio, C. mrigala, L. rohita and M. rosenbergii.

A comparative growth performance of all the species of fishes (Tables 1, 2 and 3) in terms of mean growth rate decreased with an increase in stocking density. This is probably due to the competition for food and space that caused physiological stress and relatively degraded water quality due to increased density and biomass ${ }^{43,44}$. Sinha and Ramachandran (1985) ${ }^{45}$ also reported that under crowded conditions at higher stocking density, fish suffers stress due to aggressive feeding interaction, eats less and grows slow.

Our results are also in accordance with the findings of workers who opined that growth of fish in a given pond may be expressed as a function of stocking density and stress caused by low oxygen levels at higher stocking densities ${ }^{46,47}$. The growth rate of carps like catla, rohu and mrigal were also found to be highest in polyculture ${ }^{\underline{48}}$.

Specific Growth Rate (SGR) recorded in three carp species (Table 3) showed values ranging from $2.560 \pm$ 0.091 to $3.150 \pm 0.067$ in different experimental ponds and were not statistically and significantly different from each other. Some authors have reported specific growth rate of 1.52 and 1.4 respectively in rohu fry fed with $40 \%$ protein level in the feed ${ }^{49,50}$. Mohanty et al., (1990) $)^{44}$ however, have reported optimum protein requirement 
Table 1. Growth and survival of M. rosenbergii in monoculture (MR-I) and polyculture with two carps (MR-II) and with three carps (MR-III) for 120 days

\begin{tabular}{|l|l|l|l|}
\hline Parameters & \multicolumn{1}{|c|}{ MR-I } & \multicolumn{1}{|c|}{ MR-II } & \multicolumn{1}{|c|}{ MR-III } \\
\hline Initial Mean Length, IML (cm) & $3.40 \pm 0.173^{\mathrm{a}}$ & $3.80 \pm 0.458^{\mathrm{a}}$ & $3.80 \pm 0.100^{\mathrm{a}}$ \\
\hline Final Mean Length, FML (cm) & $10.40 \pm 0.173^{\mathrm{a}}$ & $10.10 \pm 0.30^{\mathrm{a}}$ & $8.4 \pm 0.360^{\mathrm{b}}$ \\
\hline Initial Mean Weight, IMW (g) & $0.572 \pm 0.011^{\mathrm{a}}$ & $0.598 \pm 0.028^{\mathrm{a}}$ & $0.478 \pm 0.121^{\mathrm{a}}$ \\
\hline Final Mean Weight, FMW (g) & $23.842 \pm 0.321^{\mathrm{a}}$ & $18.390 \pm 0.891^{\mathrm{b}}$ & $15.236 \pm 0.360^{\mathrm{c}}$ \\
\hline Mean Weight Gain, MWG (g) & $23.270 \pm 0.267^{\mathrm{a}}$ & $17.742 \pm 0.917^{\mathrm{b}}$ & $14.758 \pm 2.246^{\mathrm{b}}$ \\
\hline Percentage Mean Weight Gain \%MWG (g) & $4068.18 \pm 304.14^{\mathrm{a}}$ & $2966.89 \pm 110.93^{\mathrm{b}}$ & $3087.45 \pm 76.62^{\mathrm{b}}$ \\
\hline Specific Growth Rate,SGR (\%W/day) & $3.108 \pm 0.084^{\mathrm{a}}$ & $2.885 \pm 0.142^{\mathrm{b}}$ & $2.852 \pm 0.114^{\mathrm{b}}$ \\
\hline Survival (\%) & $75.5 \pm 5.0^{\mathrm{a}}$ & $62.10 \pm 5.0^{\mathrm{b}}$ & $52.70 \pm 5.0^{\mathrm{c}}$ \\
\hline
\end{tabular}

Data presented above is the mean of three readings i.e. mean \pm S.D.

The values (Mean \pm S.D.) in a row having same superscript do not differ significantly $(\mathrm{P}>0.05)$.

Table 2. Growth and survival of Macrobrachium rosenbergii (MR), Cirrhinus mrigala (CM) and Labeo rohita (LR) in polyculture for 120 days

\begin{tabular}{|l|l|l|l|}
\hline \multirow{2}{*}{ Parameters } & \multicolumn{3}{|c|}{ Species } \\
\cline { 2 - 4 } & \multicolumn{1}{|c|}{ MR } & \multicolumn{1}{|c|}{ CM } \\
\hline Initial Mean Length, IML (cm) & $3.80 \pm 0.458^{\mathrm{a}}$ & $3.93 \pm 0.351^{\mathrm{a}}$ & $3.80 \pm 0.173^{\mathrm{a}}$ \\
\hline Final Mean Length, FML (cm) & $10.10 \pm 0.30^{\mathrm{c}}$ & $12.40 \pm 2.20^{\mathrm{a}}$ & $11.80 \pm 2.20^{\mathrm{b}}$ \\
\hline Initial Mean Weight, IMW (g) & $0.598 \pm 0.028^{\mathrm{a}}$ & $0.560 \pm 0.064^{\mathrm{a}}$ & $0.530 \pm 0.020^{\mathrm{a}}$ \\
\hline Final Mean Weight, FMW (g) & $18.340 \pm 0.891^{\mathrm{c}}$ & $27.40 \pm 0.662^{\mathrm{a}}$ & $23.280 \pm 2.180^{\mathrm{b}}$ \\
\hline Mean Weight Gain, MWG (g) & $17.742 \pm 0.917^{\mathrm{c}}$ & $26.840 \pm 2.425^{\mathrm{a}}$ & $22.750 \pm 1.400^{\mathrm{b}}$ \\
\hline Percentage Mean Weight Gain \%MWG (g) & $2966.89 \pm 110.93^{\mathrm{c}}$ & $4792.86 \pm 123.84^{\mathrm{a}}$ & $4292.45 \pm 268.30^{\mathrm{b}}$ \\
\hline Specific Growth Rate, SGR (\%W/day) & $2.885 \pm 0.142^{\mathrm{b}}$ & $3.243 \pm 0.048^{\mathrm{a}}$ & $3.153 \pm 0.132^{\mathrm{a}}$ \\
\hline Survival (\%) & $62.10 \pm 5.0^{\mathrm{c}}$ & $96.0 \pm 1.0^{\mathrm{a}}$ & $92.0 \pm 1.0^{\mathrm{b}}$ \\
\hline
\end{tabular}

Data presented above is the mean of three readings i.e. mean \pm S.D.

The values (Mean \pm S.D.) in a row having same superscript do not differ significantly $(\mathrm{P}>0.05)$.

Table 3. Growth and survival of Macrobrachium rosenbergii (MR), Cirrhinus mrigala (CM), Labeo rohita (LR) and Cyprinus carpio (CC) in polyculture for 120 days

\begin{tabular}{|l|l|l|l|l|}
\hline \multirow{2}{*}{ Parameters } & \multicolumn{4}{|c|}{ Species } \\
\cline { 2 - 5 } & \multicolumn{1}{|c|}{ MR } & \multicolumn{1}{|c|}{ CM } & \multicolumn{1}{c|}{ LR } & \multicolumn{1}{c|}{ CC } \\
\hline Initial Mean Length, IML (cm) & $3.80 \pm 0.100^{\mathrm{a}}$ & $3.8 \pm 0.40^{\mathrm{a}}$ & $3.7 \pm 0.10^{\mathrm{a}}$ & $3.6 \pm 0.346^{\mathrm{a}}$ \\
\hline Final Mean Length, FML (cm) & $8.4 \pm 0.360^{\mathrm{b}}$ & $10.8 \pm 0.529^{\mathrm{a}}$ & $10.2 \pm 0.854^{\mathrm{a}}$ & $10.6 \pm 0.400^{\mathrm{a}}$ \\
\hline Initial Mean Weight, IMW (g) & $0.478 \pm 0.121^{\mathrm{c}}$ & $0.552 \pm 0.046^{\mathrm{c}}$ & $0.838 \pm 0.049^{\mathrm{b}}$ & $1.210 \pm 0.046^{\mathrm{a}}$ \\
\hline Final Mean Weight, FMW (g) & $15.236 \pm 0.360^{\mathrm{c}}$ & $24.183 \pm 0.623^{\mathrm{b}}$ & $23.105 \pm 1.323^{\mathrm{b}}$ & $26.140 \pm 0.893^{\mathrm{a}}$ \\
\hline Mean Weight Gain, MWG (g) & $14.758 \pm 2.246^{\mathrm{b}}$ & $23.631 \pm 0.599^{\mathrm{a}}$ & $22.267 \pm 1.277^{\mathrm{a}}$ & $24.930 \pm 1.861^{\mathrm{a}}$ \\
\hline Percentage Mean Weight Gain, \%MWG (g) & $3087.45 \pm 76.62^{\mathrm{b}}$ & $4280.98 \pm 307.76^{\mathrm{a}}$ & $2657.160 \pm 165.43^{\mathrm{c}}$ & $2060.33 \pm 116.04^{\mathrm{d}}$ \\
\hline Specific Growth Rate, SGR (\%W/day) & $2.852 \pm 0.114^{\mathrm{a}}$ & $3.150 \pm 0.067^{\mathrm{a}}$ & $3.071 \pm 0.069^{\mathrm{a}}$ & $2.560 \pm 0.091^{\mathrm{a}}$ \\
\hline Survival (\%) & $52.70 \pm 5.0^{\mathrm{b}}$ & $94.0 \pm 1.0^{\mathrm{a}}$ & $90.0 \pm 1.0^{\mathrm{a}}$ & $95.0 \pm 1.0^{\mathrm{a}}$ \\
\hline
\end{tabular}

Data presented above is the mean of three readings i.e. mean + S.D.

The values (Mean \pm S.D.) in a row having same superscript do not differ significantly $(\mathrm{P}>0.05)$. 
in Indian major carp fry to be $40 \%$. Thus, from ongoing discussions, comparatively low protein levels (27-30\%) seem to be more ideal as compared to $40 \%$ levels; as is witnessed by higher SGR values obtained in former case. Present observations also get support from the observations made by Hossain and Kibria (2006) ${ }^{\frac{36}{6}}$ who also could obtain SGR values of prawn between 2.08-2.19 when fed formulated diets containing 30\% proteins. Also, the slower growth patterns of fishes and prawns as determined by Mohanty et al., (1990) $)^{44}$ may be attributed to lower temperature and poor food intake of fishes.

Survival of carps as recorded after the completion of the experiment can be presented as C. carpio $>$ C. mrigala $>$ L. rohita (Table 3). Such a trend can be attributed to the species-specific capabilities to procure food and meet other stress conditions under polyculture set up ${ }^{51}$. Our results are also in accordance with Das and Krishnamurty, (1960) who found that the survival of carps, particularly during initial stages of life cycle is inversely related to the number of animals in the pond. Similarly, some workers recorded significant decrease in the survival rate of all the six cultivable carp species fry beyond the densities of 0.25 million/ha ${ }^{52,53,54}$.

Prawns are suitable candidates for commercial polyculture. Experimental polyculture of $M$. rosenbergii with many species of fish is on record $11,12,23,34,55,56$. Polyculture of prawns with tilapia and grass carp or with Colorsoma and grass carp was shown to be profitable than monoculture ${ }^{55}$. Polyculture also improves the ecological balance of the pond water, preventing the formation of massive algal blooms ${ }^{57}$ and allows the use of manures as substitute for supplemental feeds ${ }^{58}$. Rouse and Stickney $(1982)^{59}$ concluded that prawn-tilapia polyculture showed higher net profit than prawn monoculture.

The present study indicates that prawn and carps are suitable combination for the optimum growth. Prawns being benthic feeders utilized the leftover food (of the fishes) that settled at the bottom, therefore, saving the feed cost. It was observed that mean size of the fish attained in the polyculture practice was almost similar to that obtained in the monoculture. As in the presence of bottom feeders, prawns could not obtain sufficient share of feed, one may therefore, conclude that a comparative low growth and survival of prawn in polyculture condition is probably due to the competition stress posed particularly by two bottom feeder species (Cyprinus carpio and Cirrhinus mrigala).

\section{Acknowledgements}

The authors are highly thankful to the Head, Department of Zoology, University of Jammu for providing necessary research facilities, Department of Fisheries Jammu and Kashmir for providing fish seed on time and DST (Government of India) for providing financial assistance.

\section{References}

1. de Man JG. On some species of the genus Palaemon Fabr with descriptions of two new forms. Notes from the Leyden Museum. 1879; 1(3):165-84.

2. Ahmed N. Prawn and Prawn Fishery of East Pakistan. Dhaka, East Pakistan: Government Press; 1957. p. 31.

3. New MB. Freshwater prawn farming: Global status, recent research and a glance at the future. Aquaculture Research. 2005; 36(3):210-30. https://doi.org/10.1111/j.13652109.2005.01237.x

4. Laxmappa B, Krishna SM. Polyculture of the freshwater prawn Macrobrachium malcolmsonii (H.M. Edwards) in Koilsagar reservoir of Mahabubnagar district (TS), India. International Journal of Fisheries and Aquatic Studies. 2015; 2(4):147-52.

5. Ling SW, Merican ABO. Notes on the life and habits of the adults and larval stages of Macrobrachium rosenbergii (de Man). Proceedings of the Indo-Pacific Fisheries Council FAO; Bangkok. 1961; 9(2):55-60.

6. Minamizawa A, Morizane T. Report on study about cultivation technique for freshwater shrimp. Ehime Prefecture Fisheries Laboratory Report (English translation). 1970.

7. Ra'anan Z, Cohen D, Rappaport U, Zohar G. The production of freshwater prawn Macrobrachium rosenbergii in Israel: The effect of added substrates on yields in a monoculture situation. Bamidgeh. 1984; 36:35-40.

8. Ra'anan Z, Cohen, D. The production of the freshwater prawn Macrobrachium rosenbergii in Israel: IL Selective stocking of size subpopulations. Aquaculture. 1983; 31:369-79. https://doi.org/10.1016/0044-8486(83)90326-5

9. Malecha SR, Buck DH, Izuka DR. Polyculture of freshwater prawn, Macrobrachium rosenbergii, Chinese and common carps in ponds enriched with swine manure. Aquaculture. 1981; 10:101-6. https://doi.org/10.1016/00448486(81)90173-3

10. Hoq, ME, Islam MM,Hossain M.M. Polyculture offreshwater prawn $(M$. rosenbergii) with Chinese and Indian major carps in farmer's pond. Journal of Aquaculture in tropics. 1996; $11: 135-41$. 
11. Alam MJ, Jahan DA, Pramanik WA, Hoq ME. Polyculture of freshwater prawn, Macrobrachium rosenbergii (de Man). Bangladesh Journal of Fisheries. 2001; 5:135-44.

12. Ranjeet K, Kurup BM. Heterogeneous individual growth Macrobrachium rosenbergii male morphophytes. Naga, The ICLARM Quarterly. 2002; 25:13-8.

13. Dhert P, Sorgeloos P. Live feeds in Aquaculture. Infofish International. 1995; 2(95):31-9.

14. Stottrup JG. The elusive copepods: Their production and suitability in marine aquaculture. Aquaculture Research. 2000; 31:703-11. https://doi.org/10.1046/j.13652109.2000.318488.x

15. Kuru BM, Ranjeet K. Integration of freshwater prawn culture with rice farming in Kuttanad, India. Naga, World Fish Center Quarterly. 2002; 25:16-9.

16. Langer S, Bakhtiyar Y, Malik N, Karlopia SK. Growth, survival and proximate body composition of M. dayanum larvae fed artificial food and natural food organisms under laboratory conditions. International Journal of Biotechnology and Biochemistry. 2009a; 5(3):213-21.

17. Langer S, Bakhtiyar Y, Lakhnotra R. Replacement of fishmeal with locally available ingredients in diet composition of Macrobrachium dayanum. African Journal of Agricultural Research. 2011a; 6(5):1080-4.

18. Bakhtiyar Y, Lakhnotra R, Langer S. Natural food and feeding habits of a locally available freshwater prawn Macrobrachium dayanum (Henderson) from Jammu waters, North India. International Journal of Fisheries and Aquatic Studies. 2013; 2(3):33-8.

19. Bakhtiyar Y, Samyal A, Langer S. Studies on the effect of delayed initial feeding on survival of Macrobrachium dayanum (Henderson) larvae under laboratory conditions. International Journal of Fisheries and Aquatic Studies. 2015; 3(2):463-7.

20. Bakhtiyar Y, Langer S. Seasonal variation in the proximate body composition of Macrobrachium dayanum (Henderson, 1893) (Decapoda, Caridea) from Gho-Manhasa stream, Jammu, North India. Acta Biologica Turcica. 2016; 29(3):89-98.

21. Langer S, Karlopia SK, Bakhtiyar Y. Effect of different feeds on the growth and survival of post larvae of fresh water prawn Macrobrachium rosenbergii in Jammu. National Journal of Life Sciences. 2009b; 6(2):187-92.

22. Langer S, Karlopia SK, Bakhtiyar Y. Effect of different stocking densities on the growth and survival of freshwater prawn, Macrobrachium rosenbergii under laboratory conditions in Jammu. International Journal of Fisheries and Aquaculture Sciences. 2011b; 1(1):19-25.

23. Mohapatra BC, Singh SK, Surkar B, Majhi D, Sarangi, N. Observation of Carp Polyculture with giant freshwater prawn in solar heated fish pond. Journal of Fisheries and Aquatic Science. 2007; 2(2):149-55. https://doi. org/10.3923/jfas.2007.149.155

24. Duncan DB. Multiple range and multiple ' $F$ ' tests. Biometrics. 1955; 11:1-42. https://doi.org/10.2307/3001478

25. Chowdhury R, Bhattacharjee H, Angell C. A manual for operating freshwater prawn hatchery. Madras, India: BOBP/MAG/BOBP; 1991. p. 1336.

26. TidwellJH, CoyleSD, Dasgupta S. Effects of stocking different fractions of size graded juvenile prawns on production and population structure during a temperature-limited grow out period. Aquaculture. 2004; 231(1-4):123-34. https:// doi.org/10.1016/S0044-8486(03)00544-1

27. Fujimura T, Okamoto H. Notes on the progress made in developing a mass culture technique for Macrobrachium rosenbergii in Hawaii. Indo-Pacific Fisheries Council Proceedings, 14 $4^{\text {th }}$ Session; Bangkok, Thialand. 1970. p. 17.

28. Tunsutapanich A, Chalaypote S, Phuhoung P. Macrobrachium farming in areas with irregular water supply. Giant Prawn 1980: An International Conference on Macrobrachium (Freshwater Prawn) Farming; Bangkok, Thailand. 1980.

29. Popper DM, Davidson R. An experiment in rearing freshwater prawns in brackish water. Developments in Aquaculture and Fisheries Science. 1982; 10:173.

30. Shirgur GA, Chavan JB, Indulkar ST, Siddique SQ. Extensive pond culture of freshwater, Macrobrachium rosenbergii. Aquaculture Productivity. V. R. P. Stanna, Editor. Article No. 36. Freshwater culture. 1988. p. 429-38.

31. Raje PC, Joshi VP. Multilocational grow-out trials of Macrobrachium rosenbergii in Western Maharashtra. Proc Freshwater Prawns. College of Fisheries. Panangad, Kerala Agricultural University; 1992. 180-2.

32. Indulkar ST, Belsare SS, Ranade AM, Raje PC. Culture of giant fresh water prawn Macrobrachium rosenbergii with low inputs in Ratnagiri District of Maharashra. Proc Zool Soc India. 2007; 6(1):1-5.

33. El-Sherif MS, Ali-Mervat AM. Effect of rearing systems (Mono and Polyculture) on the Performance of Freshwater Prawn (M. rosenbergii) Juveniles. Journal of Fisheries and Aquatic Science. 2009; 4(3):117-28.

34. Haque MM, Narejo NR, Salam MA, Rahmatullah SM, Islam MA. Determination of optimum stocking density of Macrobrachium rosenbergii in carp polyculture in earthen pond. Pakistan Journal of Biological Sciences. 2003; 16:898-901. https://doi.org/10.3923/pjbs.2003.898.901

35. Trino ST, Penaflorida VD, Holiver EC. Growth and survival of Penaeus monodon juveniles fed at diet lacking vitamin supplements in a modified extensive culture system. Aquaculture. 1992; 101:25-32. https://doi. org/10.1016/0044-8486(92)90229-E 
36. Hossain MA, Kibria AS. Over-wintering growth of Macrobrachium rosenbergii (de Man) with carp polyculture in Bangladesh fed formulated diets. Aquaculture Research. 2006 Sep; 37(13):1334-40. https://doi.org/10.1111/j.13652109.2006.01571.x

37. Siddique MA, Hossain MA, Miaje MA. Polyculture of giant freshwater prawn, Macrobrachium rosenbergii with Indian major carps in ponds with supplemental feed. Bangladesh Journal of Fisheries. 1999; 22:67-74.

38. Ali ML, Hossain MG, Ahsan CT, Mazid MA. Impact of silver barb (Barbades gonionotus) on growth and survival of prawn (Macrobrachium rosenbergii) in polyculture system. J Agric Univ. 2003; 1:99-104.

39. Hossain MA, Islam MS. Optimization of stocking density of freshwater prawn Macrobrachium rosenbergii (de Man) in carp polyculture in Bangladesh. Aquaculture Research. 2006; 37(10):994-1000. https://doi.org/10.1111/j.13652109.2006.01518.x

40. Vijayan MM, Varghese TJ. Effect of artificial aeration on growth and survival of Indian major carps. Proc Indian Acad Sci. (Anim Sci). 1986; 95(4):371-8. https://doi. org/10.1007/BF03179371

41. Sinha VRP. Breeding and culture of Indian Major Carp. Ahmed,S.H.Editor.Advancesinfisheriesandfishproduction. New Delhi, India: Hindustan Publishing Corporation; 1998. p. 309.

42. Mohanty P. Growth performance of Penaeus monodon at different stocking density. J Inland Fish Soc.1999; 31:44-9.

43. Trzebiatowski R, Filipiak J, Jakubowski R. Effect of stock density on growth and survival of rainbow trout (Salmo gairdneri Rich.). Aquaculture. 1981; 22:289-95. https://doi. org/10.1016/0044-8486(81)90155-1

44. Mohanty SN, Swamy DN, Tripathi SD. Protein utilization in Indian major carp fry Catla catla (Ham.), Labeo rohita(Ham.) and Cirrhinus mrigala (Ham.) fed with four protein diets. J Aquacult Trop. 1990; 5:173-9.

45. Sinha VRP, Ramachandran V. Freshwater fish culture. New Delhi: Indian Council of Agricultural Research; 1985. p. 80.

46. Wedemeyer GA. Physiological response of juvenile coho salmon (Oncorhynchus kisutch) and rainbow trout (Salmo gairdneri) to handling and crowding stress in intensive fish culture. J Fish Res Board Canada. 1976; 33:2699-702. https://doi.org/10.1139/f76-320

47. Fagerlund UHM, McBride JR, Stone ET. Stress related effects of hatchery rearing density on coho salmon. Trans Am Fish Soc.1981; 110:644-9. https://doi.org/10.1577/15488659(1981) $110<644:$ SEOHRD $>2.0$. CO;2

48. John KR, Venkataswamy M, Sundraraj V. Monoculture bispecies culture and composite culture of Macrobrachium rosenbergii and Macrobrachium malcolmsonii. J Aquacult Trop.1995; 10:37-41.
49. Hassan MA, Jafri AK, Khan MA, Anwar MF, Erfanullah. Effect of varying dietary energy to protein ratio on the growth, feed efficiency and carcass composition of Labeo rohita fingerlings. Proc Nat Symp Freshwat Aquacult; Bhubaneswar, India. 1991. p. 78-80.

50. Rangacharyulu PV, Sarker S, Mohanty SN, Das KM, Mukhopadhayay PK. Growth and protein utilization in rohu, Labeo rohita under different feeding levels. National Symposium on new Horizons in Fresh water. Aquaculture. 1991; 91:95-7.

51. Mohanty RK. Feed intake pattern and growth performance of Indian major carps, common carp and freshwater prawn in a rice-fish integration system. Asian Fisheries Science. 2003; 16:307-16.

52. Das T, Krishnamurthy H. Survival rates of Indian carp (Catla catla, Labeo rohita, Cirrhinus mrigala) from the first to fourth week of life under different experimental treatments. Sankhya. 1960; 23:311-6.

53. Murty DS, Saha GN, Seevaraj C, Reddy PV, Dey RK. Studies on increased fish production in composite fish culture through nitrogenous fertilization with and without supplementary feeding. J Inland Fish Soc India. 1978; 10:39-45.

54. Sen PR, Chakraborty RD. Rearing of major carp fry to fingerlings in freshwater ponds. Symposium on Inland Aquaculture; 1979 Feb. p. 12-4.

55. Engle CR. Economic analysis of the commercial production of Tilapia, Colossoma and Macrobrachium rosenbergii in monoculture. Review of Latinoamerica. Aquaculture. 1987; 33:6-25.

56. Ghosh S, Ranjan R, Megharajan S, Pattnaik P, Dash B, Edward, L. Mixed culture of Pacific white shrimp Litopenaeus vannamei (Boone, 1931) and flathead grey mullet Mugil cephalus (Linnaeus, 1758) in floating cages. Indian Journal of Fisheries. 2016; 61(3):63-9. https://doi. org/10.21077/ijf.2016.63.3.56378-08

57. Cohen D, Ra'anan Z, Barnes A. Production of the freshwater prawn Macrobrachium rosenbergii in Israel. 1. Intergration into polyculture systems. Aquaculture. 1983; 31:67-76. https://doi.org/10.1016/0044-8486(83)90258-2

58. Maor R, Wohlfoth G, Schroeder GL, Haulata G, Barash $H$. Intensive polyculture of fish in freshwater ponds. Substitution of expensive feeds liquid cow manure. Aquaculture. 1977; 10:25-43. https://doi.org/10.1016/00448486(77)90030-8

59. Rouse DB, Stickney RR. Evaluation of the production potential of Macrobrachiurn rosenbergii in monoculture and in polyculture with Tilapia aurea. Journal of the World Mariculture Society. 1982; 13:73-85. https://doi. org/10.1111/j.1749-7345.1982.tb00014.x 